\title{
Effect of Annealing Temperature of Gold Doped Reduced Graphene Oxide Counter Electrode on the Performance of Dye- sensitized Solar Cell
}

\author{
M.Y.A. Rahman ${ }^{*}$, A.S. Sulaiman, A.A. Umar \\ Institute of Microengineering and Nanoelectronics (IMEN), Universiti Kebangsaan Malaysia, 43600, \\ Bangi, Selangor, Malaysia \\ *E-mail: mohd.yusri@ukm.edu.my
}

doi: $10.20964 / 2018.06 .10$

Received: 15 January 2018 / Accepted: 5 March 2018 / Published: 10 May 2018

This paper is concerned with the use of gold doped reduced graphene oxide (rGO) films, replacing costly platinum films as a counter electrode in dye-sensitized solar cell (DSSC). The influence of annealing treatment of the electrode on the performance parameters of the device has been investigated. The XRD analysis reveals that crystallite size of GO increases with annealing temperature. The $140{ }^{\circ} \mathrm{C}$ sample possesses the highest transmission in visible region. The DSSC utilizing the sample annealed at $120{ }^{\circ} \mathrm{C}$ performed the highest $\eta$ of $0.134 \%$, respectively due to the longest carrier lifetime.

Keywords: annealing treatment, counter electrode, dye-sensitized solar cell, gold, graphene oxide

\section{FULL TEXT}

(C) 2018 The Authors. Published by ESG (www.electrochemsci.org). This article is an open access article distributed under the terms and conditions of the Creative Commons Attribution license (http://creativecommons.org/licenses/by/4.0/). 